\title{
Anthropogenic transformation of the relief of the Aegean Islands
}

\begin{abstract}
The purpose of this article is to present the role of human impact in the forming and transformation of the relief of the Aegean Islands. The most significant changes (with a displacement of more than $10 \mathrm{bln} \mathrm{m}^{3}$ of rock material) are related to the creation of road infrastructure and the construction of agricultural terraces. In order to create stone buildings, $20 \mathrm{mln} \mathrm{m}^{3}$ of rock material was used; for the purposes of air transport a surface area of nearly $2.5 \mathrm{~km}^{2}$ was levelled; many kilometres of artificial shorelines were created and at least $4.5 \mathrm{mln} \mathrm{m}^{3}$ of material was displaced for the purposes of the construction of artificial reservoirs of a total capacity of more than $25 \mathrm{mln} \mathrm{m}^{3}$. A huge amount of material was removed as a result of mining activities. The indirect impact of economic activities on the relief of the discussed area includes mainly slope, fluvial and coastal processes.
\end{abstract}

Keywords

Relief • geomorphological processes • human impact • Aegean Islands

(C) University of Warsaw - Faculty of Geography and Regional Studies
Irena Tsermegas

Department of Geomorphology Institute of Physical Geography Faculty of Geography and Regional Studies University of Warsaw Poland

e-mail: argiro@uw.edu.pl

Received: 16 April 2015

Accepted: 15 June 2015
Introduction

The human impact on relief transformation, resulting in the appearance of new artificial landforms or the transformation of already existing natural landforms, seen also through the modification of the course of morphogenetic processes, is a theme which is more and more frequently the subject of geomorphological research (Szabó 2006). However, even though 150 years have passed since the publication of G.P. Marsh's work (1864), the first publication concerning the role people play in the process of transforming nature around them, recognition of both the quality and quantity aspects of this form of human impact is still not sufficient in many areas (Goudie 1993, Hooke 2000, Rozsa 2007). This applies to some regions of Europe, including the Aegean Islands.

The purpose of this research is to present the role of human impact in the formation of the current relief of the Aegean Islands. This article constitutes a first attempt to define the general sizes, as well as the spatial and age diversity, of anthropogenic landforms in order to distinguish the most important stages of the formation of the most basic morphological elements of the cultural landscape of this area. The author has tried to synthesize data from various studies, including her own research. The current degree of human-induced transformation of the relief and the course of contemporary anthropogenic processes have been assessed on the basis of the results of the author's own field studies carried out on the islands of Ikaria and Santorini, within the framework of the research project "Degradation of terraced slopes in Mediterranean conditions"1 as well as the analysis of

${ }^{1}$ The research was financed by MNiSW / NCN grant No. N N306 469239. topographic maps, and the transformations have been analysed from a historical perspective on the basis of information from written sources.

\section{Area of research}

In this paper the Aegean Islands (Fig. 1) were treated in accordance with their formal status as a geographical unit including approximately 2800 islands (Kizos, Spilianis \& Koulouri. 2007), of which 69 are inhabited, located within Greek territory. They cover an area of nearly $9000 \mathrm{~km}^{2}$. The islands belonging to Turkey (250 islands) were not taken into consideration. Crete, Euboea and the islands of the Saronic Gulf were not included in the research. Also, Kythira and Antikythera were omitted as, despite the fact that they are partially surrounded by the waters of the Aegean Sea, they are mostly considered to be part of the Ionian Islands.

In the geology of the considered islands the following crystalline rocks predominate: gneisses, schists, granitoids and marbles. On the southern and eastern ends of the archipelago volcanic rocks with a high proportion of tuffs are common. Sedimentary rocks occupy a much smaller area (Geological Map of Greece 1983). The soils developed on such a surface are mostly rocky - the surface area is occupied by shallow stony soils (Leptosols), as well as Cambisols and Luvisols without a welldeveloped structure (Yassoglou 2005). The majority of the discussed islands, especially the large ones, have a typically mountainous relief - only a few islands have peaks with an elevation not exceeding $300 \mathrm{~m}$ a.s.l., and on most of them the highest peaks reach $500 \mathrm{~m}$ a.s.l. or more. The significant amount of steep 


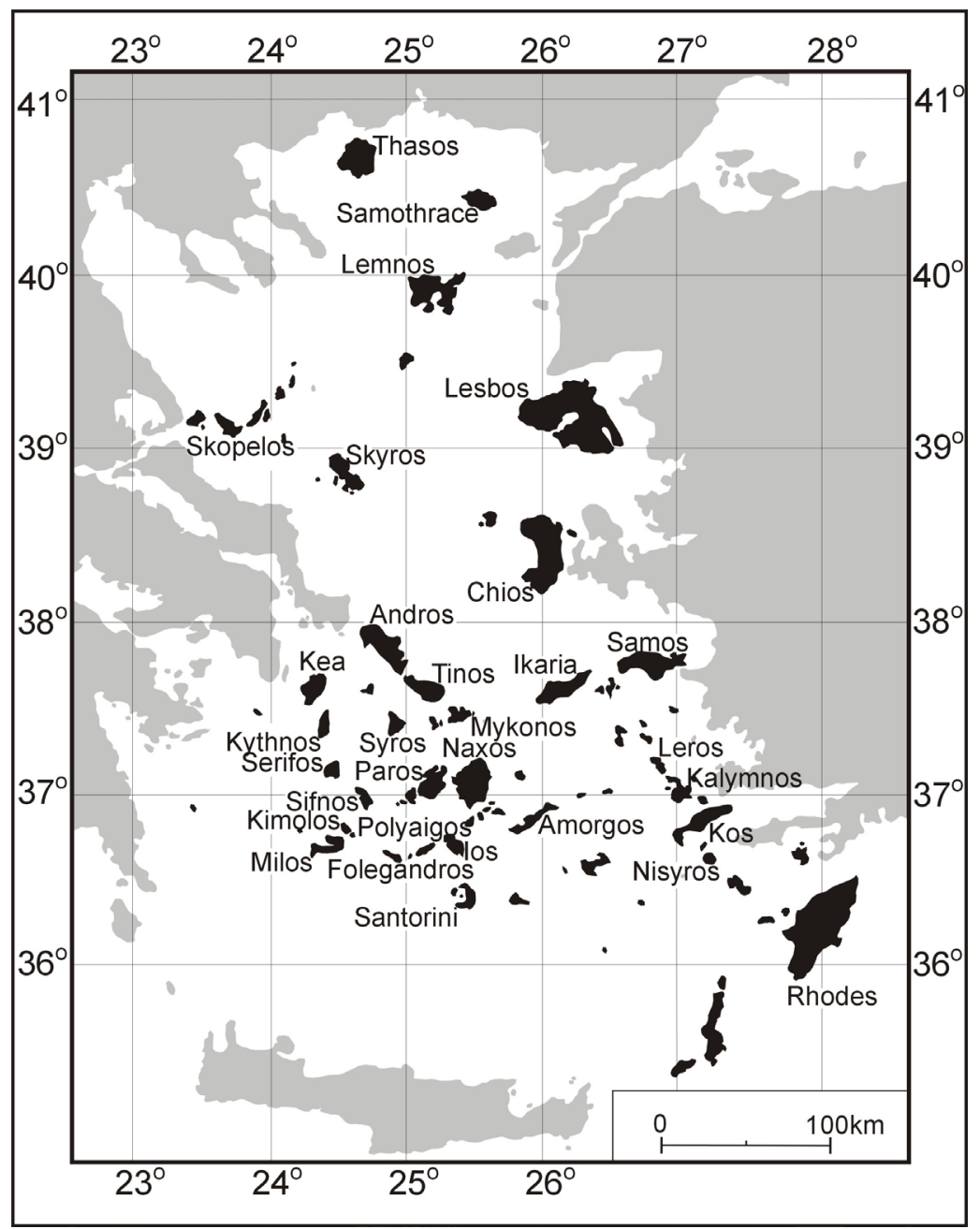

Figure 1. Location of the Aegean Archipelago and the islands mentioned in the text

slopes has constituted a natural limitation of possibilities for the development of certain areas, while the transformation of the relief has also remained a problem. However, in such conditions, those parts of the areas which, due to a convenient relief, could be relatively easily developed (mostly valley bottoms, gentle slopes and coastal areas) were subject to a more significant human impact (Bintliff 1977, Kizos et al. 2007).

A mild, typically Mediterranean climate since the beginning of the Holocene promoted the colonization of the archipelago and later allowed the development of agricultural production (Wiener 2013). Simultaneously, the occurrence of seasonal precipitation contrast - especially the occurrence of heavy autumn and winter rains after very dry summers - has constituted an important impetus in increasing the intensity of erosion on surfaces deprived of natural vegetation cover (García-Ruiz et al. 2013).

Signs of human presence in the area widely understood to be the Aegean region indicate that people have been present there since the Late Middle Pleistocene period. Most probably the islands were inhabited later; however, one needs to consider the fact that a significant part of the coastal archaeological sites from that period was not preserved due to the post-glacial sea level rise. Nonetheless, numerous factors indicate that 130000 years BP at least some of the discussed islands, even though they were not colonized, were visited by people who travelled across the Aegean Sea, moving between the already inhabited continental coasts (Runnels 2014). The oldest preserved signs of the short-term functioning settlements related to seafaring are known from the islands of Gioura and Kythnos (Sampson 2010) and from the island of Ikaria (Sampson et al. 2012). They come from the $9^{\text {th }}$ millennium BC. The beginnings of the permanent colonization of the majority of the islands reach back to the $7^{\text {th }}$ millennium BC (Broodbank 1999). There is no detailed data regarding how the population of the Aegean Islands changed over the centuries. Despite the general upward trend, there were also periods in which, as a result of invasions or epidemics, certain islands were depopulated. Most likely the largest number of people settled on the islands in the second half of the $19^{\text {th }}$ century and at the beginning of the $20^{\text {th }}$ century (Petmezas 2007). Since the middle of the last century a depopulation of the majority of the islands has been taking place, especially on the small islands; however, thanks to the development of tourism, on some islands there are several times more people in the summer season than in winter. For instance, the number of tourists who visit Santorini (Thira) each year exceeds the number of its permanent inhabitants more than one hundred times.

\section{Anthropogenic landforms}

In practical terms, every type of human activity results in changes to a landscape. Firstly the changes usually concern vegetation. The transformation of other components most frequently requires greater physical and financial efforts. This concerns the relief in particular, and the landforms occurring as 
a result of various economic impacts are mostly clearly visible, extensive and durable (Nir 1983, Hooke 2000).

Similarly to other regions on the Earth (Nir 1983, Podgórski 2001), the anthropogenic forms present in the relief of the Aegean archipelago have emerged and are emerging mainly as a result of the impact of such sectors of the economy as: settlement (e.g. excavation for foundations, slope fragments artificially flattened for development, stone buildings), communication (road cuts and fills, harbour breakwaters, airport runways, tunnels), water management (artificial reservoirs, channelled or covered riverbeds), agriculture (agricultural terraces, stone barriers and pens for farm animals), mining (quarries, mine shafts, spoil tips, routes for the transport of excavated materials), cult activities - to fulfil spiritual needs (surfaces artificially flattened in order to build temples and cemeteries), military activities (forms which emerge in relation to the construction of fortifications - embankments, moats) and recreation (transformed and artificial beaches, sports fields).

Among the oldest forms, related to human residential needs, which result in the establishment of individual houses and the entire settlement system, special attention in the case of the Aegean Islands should be paid to: artificially undercut segments of the slopes or segments flattened for development (Fig. 2A) and stone buildings (constructed from the local rocks; Fig. 2B). The necessity to dispose of municipal waste is indirectly connected to basic human livelihood needs.

Buildings are constructed on relatively flat coastal plains or on slopes of up to a $10^{\circ}$ incline - only in very rare cases on steeper surfaces, but within locally flattened areas. There are a few plains at the bottom of valleys on the islands. These are used for cultivation, so it is very rare for them to be built on. Towns are usually located in the lower parts of the valley slopes. This requires the undercutting of the slope. Simultaneously, due to the prevalence of solid bedrock, excavations for foundations are normally shallow or non-existent. In the last several years, buildings have mostly been built using materials imported from outside the archipelago, while earlier they were mainly built from local stone materials. From previous calculations conducted by the author it can be concluded that it was necessary to use at least $600000 \mathrm{~m}^{3}$ of rocks to create the existing stone buildings on Ikaria, an island with a surface area of $255 \mathrm{~km}^{2}$ (Tsermegas 2012a). Proportionally, within the entire archipelago, significantly more than $20 \mathrm{mln} \mathrm{m}^{3}$ (approx. $50 \mathrm{mln} \mathrm{t}$ ) of rock has been used for building houses over the centuries. It should be underlined that the building materials were used multiple times - to build new houses, materials from the demolition of older buildings were used, which did not promote the preservation of ancient structures.

According to data from the Greek Ministry of Environment, Energy and Climate Change, there are currently 18 functioning landfills on the Aegean Islands (YPEKA 2012). Additionally, there have been more than 40 similar facilities excluded from usage during the last 10 years, as well as several hundred older small landfills. As can be concluded from Eurostat data (Bakas \& Milios 2013), an average resident of Greece produces approximately $500 \mathrm{~kg}$ of rubbish per year, $4 / 5$ of which goes to landfill. On the Aegean Islands there are 500000 permanent residents, while in the summer season the number of people is several times larger. Therefore, at least 200 000-300 000 tons of waste go to landfill. This means that in the last fifty years the mass of waste produced by the residents of the discussed islands was at least $12 \mathrm{mln}$ tons.

The scale of transformations related to transport is also very significant. The construction of roads in this area of diverse relief required many kilometres of road cuts and fills; in one case it even required hollowing a tunnel-like structure with a length of nearly $300 \mathrm{~m}$, which was created at the end of the last century on
Ikaria. The length of the road network on one large island (such as Naxos) reaches approximately $500 \mathrm{~km}$. The vast majority of them have durable surfaces, therefore constituting permanent landforms. Vehicular transportation was only popularized on the Aegean Islands in the second half of the $20^{\text {th }}$ century. Earlier, mainly stone set roads (Fig. $2 \mathrm{C}$ ) and paths were created. Their surface was made of beach pebbles, among other things especially on the islands of Dodecanese and locally on the Cyclades.

In order to cover 100 meters of a road up to several tons of material were used. According to the author's estimation based on field observations, in the conditions of mountainous relief typical for the islands, the construction of $1 \mathrm{~km}$ of a road means - depending on the slope angle - the displacement of approximately $2000 \mathrm{~m}^{3}$ (on an incline of up to $10^{\circ}$ ) to $7000 \mathrm{~m}^{3}$ (on an incline of more than $25-30^{\circ}$ ). As can be concluded from topographic maps (scale 1:50,000), on the Aegean Islands the road network density, the demarcation of which required a significant transformation of the relief, is at least $0.5 \mathrm{~km} / \mathrm{km}^{2}$. Therefore, within the whole archipelago, the displacement of more than $10 \mathrm{bln} \mathrm{m}^{3}$ of solid and weathered rocks was required in order to create the road infrastructure.

Transport needs have resulted in the occurrence of many harbours on the Aegean Islands. Despite the favourable shoreline configuration, the assurance of seamanship safety required the construction of stone and concrete wharfs and breakwaters (Fig. 3) extending into the sea. On each of the discussed islands there are a few to several dozen constructions of this sort in use. Some of them are $400 \mathrm{~m}$ or more in length. Their presence has significantly changed the natural relief of the coast - curved lines have been replaced by straight ones.

Artificially flattened surfaces are especially widespread anthropogenic landforms related to transport within the analysed archipelago. Airport runways are located on such surfaces, twenty of which are found on the Aegean Islands. They vary in length between $1000 \mathrm{~m}$ (on Paros) and $3500 \mathrm{~m}$ (on Skyros). In the majority of cases, surfaces with low relief diversity and small slope gradients were levelled. However, when there was no other option, a part of the runway was constructed on an artificial or transformed foreland extending into the sea (on Skyros, Leros and Ikaria - Fig. 2D). On Kalymnos the surface of a wide low hill was flattened for the needs of an airport, and on Kos a fragment of a plateau with incised valleys was levelled. According to the author's calculation, the surface area of all Aegean airports is estimated as at least $2.5 \mathrm{~km}^{2}$.

Artificially levelled fragments of mountain ridges, on which mobile telephone antennas, radio and television masts, and satellite relay stations are placed, should also be considered specific landforms related to communication (electronic communication). Such facilities function on all the larger and several of the smaller islands. Similar changes to the relief, although usually larger in scale due to the multiple occurrence, are connected to the construction of wind power plant masts. The first masts were built on the analysed area in the 1980s. Previously they were mainly small structures and their impact on the relief could have been considered negligible. However, the construction of more than 350 wind turbines on Lesbos, Chios and Lemnos is planned for the near future. In order to locate a single turbine it is necessary to lay foundations with the dimensions $15.2 \times 15.2 \mathrm{~m}$, embedded to a depth of $2.4 \mathrm{~m}$ (Terkenli \& Pavlis 2012). More than 300 of these turbines will be also placed on the highest elevations of the Cyclades, including 31 on the uninhibited Polyaigos. This means that together, as a result of the direct impact of these investments, more than 360000 $\mathrm{m}^{3}$ of rock material will be displaced. It is worth highlighting that the necessity to construct several hundred kilometres of new 


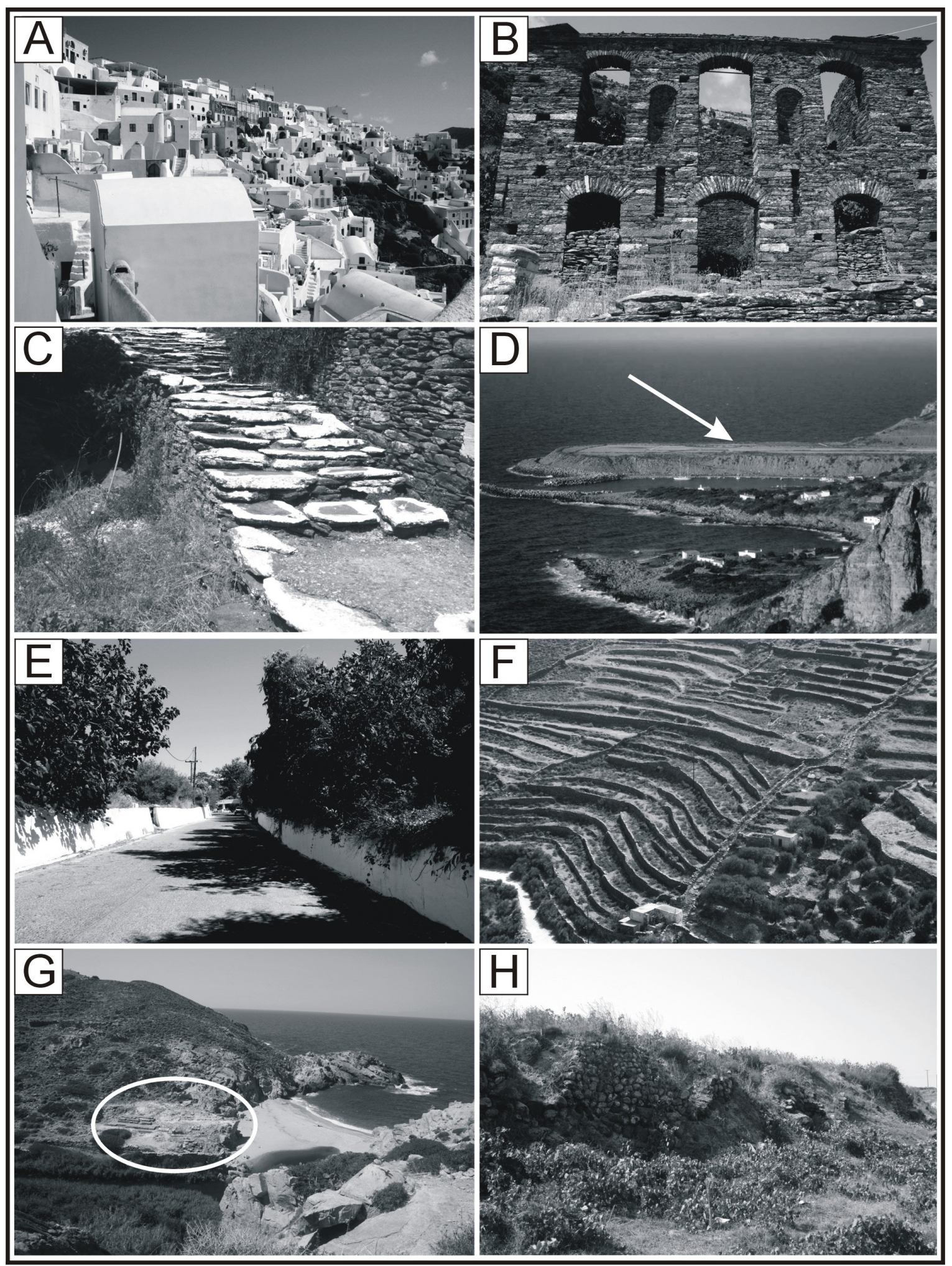

Figure 2. Examples of anthropogenic landforms on the Aegean Islands: $A$ - dense development on a slope (Fira on Santorini), $B-$ ruins of a stone building (Mavrato, Ikaria), $C$ - a road fragment paved with crystalline schist (Mavrato, Ikaria), D - an airport runway extending into the sea on Ikaria, E - a fragment of a river channel transformed into a road (Therma, Ikaria), Fagricultural terraces on Siros, G - ruins of the Temple of Artemis in Nas on Ikaria, located on an artificially levelled fragment of a footslope, $\mathrm{H}$ - a destroyed edge of an agricultural terrace on volcanic tuffs (Pirgos, Thira Island) 


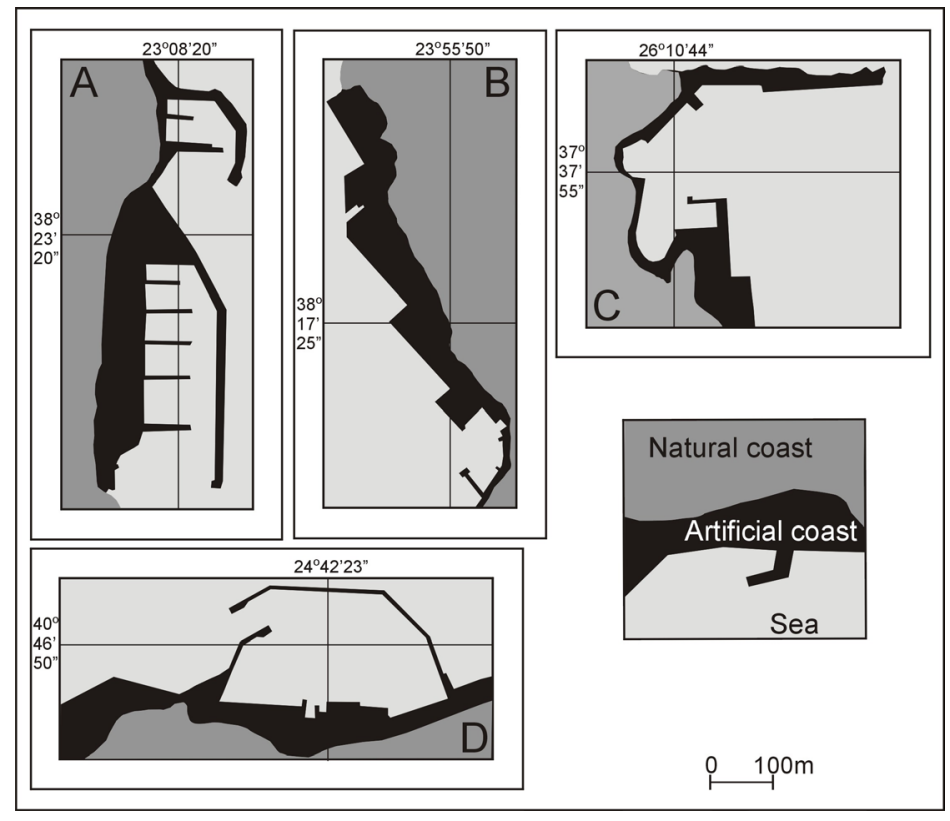

Figure 3. Examples of artificial shorelines on the following islands: Chios (A, B), Ikaria (C) and Thasos (D).

- mostly unsealed - roads is related to the construction of the above-mentioned antennas and wind turbines.

Further significant changes in the relief of the Aegean Islands are connected to water management, especially with the creation of artificial water reservoirs. Small artificial water reservoirs, collecting water mainly in the vicinity of springs, functioned there for several hundred years, but at the end of $20^{\text {th }}$ century the larger rivers started to be dammed and construction began on large reservoirs to collect rain water. There are currently more than 40 artificial water reservoirs functioning there, of which 30 have a cubature larger than $200000 \mathrm{~m}^{3}$ (Michas, Economides \& Tsialas 2008). Their total surface area is $3.8 \mathrm{~km}^{2}$, and their volume more than $25 \mathrm{mln} \mathrm{m}^{3}$. The construction of dams and embankments required the displacement of at least $4.5 \mathrm{mln} \mathrm{m}^{3}$ of material (they are mostly earthfill dams). The largest artificial reservoir on the Aegean Islands was created by a dam with a height of $46.7 \mathrm{~m}$ on the Apolakkia stream on Rhodes. Its surface area is $720000 \mathrm{~m}^{2}$ and it can contain $8.1 \mathrm{mln} \mathrm{m}^{3}$ of water (The dams of Greece 2013), but larger structures are currently under construction.

Significant anthropogenic transformations also included the Aegean river and stream channels. The fact that the majority of the watercourses on the discussed islands remain dry or have little water for the majority of the year promoted these transformations. River and creek channels were artificially narrowed when in close proximity to towns, and in many cases also strengthened and changed into roads or covered (Fig. 2E). The parts beyond the built-up areas remain unchanged along most of their length or their transformations were merely of a point nature (Tsermegas 2012b).

From a spatial perspective, the largest changes in the relief of the Aegean Islands were introduced by agricultural activities. The scarcity of flat surfaces, required for cultivation, forced the residents of the discussed region to create extensive systems of agricultural terraces. The first forms of this sort were probably created in the Bronze Age; however, they were not common at that time (Betancourt \& Hope Simpson 1992). It is still unclear what the range of the terraces was in the Classical Antiquity, but there is evidence showing that, for example on Delos, they were being built as early as the $5^{\text {th }}$ century BC (Brunet 1999). However, the majority of agricultural terraces within the discussed archipelago were created much later, probably in the period of the Ottoman Empire (15-19 $9^{\text {th }}$ centuries), and their most significant range was observed at the end of the $19^{\text {th }}$ century and the beginning of the $20^{\text {th }}$ century (Kizos \& Koulouri 2006, Papanastasis 2007), although later it decreased systematically (Giourga, Margaris \& Vokou 1998).

The most common form of agricultural terraces on the Aegean Islands is the typical bench terrace, both parallel and braided, varying in width and height. These parameters are usually related to the slope gradient and the use of particular terraces. Moreover, locally there are also valley floor terraces and cross-channel terraces, as well as enclosed fields which create a checkered pattern, where the particular fields differ slightly in their relative height. Within the olive plantation on Lesbos, and very rarely on other islands, pocket terraces were created - hemispherical forms for a single tree (Grove \& Rackham 2001, Tsermegas 2013).

A particularly large proportion of terraces in relation to the general surface area is typical for small islands, especially those which constitute a part of the Cyclades and the majority of islands on which volcanic rocks, especially young tuffs, predominate. On many islands more than half of the slopes have been changed into systems of terraces and these forms occur as large and compact complexes (e.g. on Folegandros, los, Kythnos, Syros Fig. 2F, Sifnos, Nisyros). On only a few islands - mainly the large or extraordinarily rocky islands - less than 20-30 per cent of the surface area was transformed into terraces; an especially small number of terraced slopes is typical for Rhodes and Samothrace. In accordance with careful estimates, the construction of all the agricultural terraces currently present in the land form of the Aegean Islands was related to the displacement of at least 400 $\mathrm{mln} \mathrm{m}^{3}$ of rocky material and soil (Tsermegas 2013). It is necessary to highlight that over the centuries some of the terraces were destroyed and these were not taken into consideration in the above-mentioned estimates; the remaining terraces were probably destroyed and rebuilt many times (Whitelaw 1994), and therefore the material used to build them was displaced more than once.

Dry stone walls, which function as boundaries and fences, constitute a specific form related to agricultural land use, and 


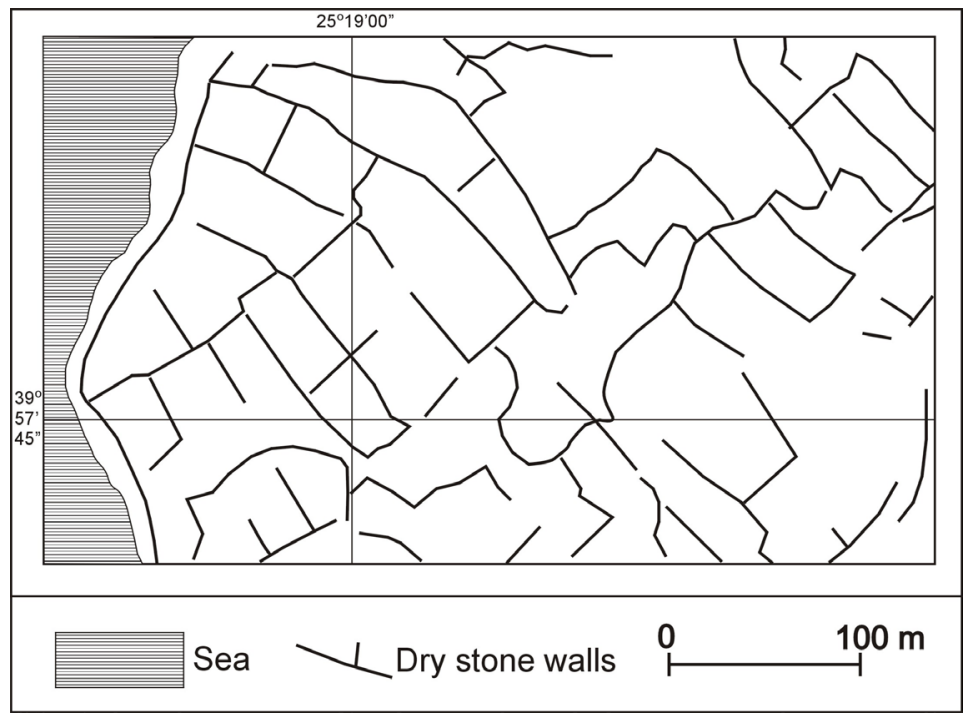

Figure 4. Dry stone wall network on the NW coast of Limnos.

occur on nearly all the discussed islands. It is hard to determine the length of such forms on the entire archipelago, but on some islands their density can reach more than $30 \mathrm{~km} / \mathrm{km}^{2}$ (e.g. on Lemnos, as it can be seen in Fig. 4).

Due to a complex geological past and tectonics, the Aegean Islands constitute an area where numerous mineral resources occur. Some of them have been exploited since the prehistoric era. For instance, obsidian from Milos was found in the settlements of the Franchthi cave on the Peloponnese dating back to the $11^{\text {th }}$ millennium $\mathrm{BP}$, but a lot of factors indicate that it was extracted much earlier (Laskaris et al. 2011). Signs of this prehistoric exploitation have been preserved on Milos to this day in the region of Adamantas. Other volcanic rocks, commonly appearing in different parts of the Aegean Sea, were also used by people since the beginning of their presence in the region. For instance, trachytes from Milos, Kimolos, Polyaigos, Santorini, Nisyros, Lemnos and Lesbos were used to produce quernstones. Some sandstones were exploited on Skyros and Rhodes for similar purposes. Resources which were also significantly exploited include the following: pozzolan tuff from Santorini, used for example during the construction works of the Suez Canal (in the middle of the $20^{\text {th }}$ century the exploitation reached $120000 \mathrm{t}$ annually - Leivarados 2001), and kaolinite from Kimolos and Milos. On the Aegean Islands there are also rich deposits of high quality marble. In ancient times they were most significantly exploited on Thasos, Skyros, Paros and Naxos. Small marble quarries are still preserved on numerous other islands. Significantly smaller than opencast mining, but nonetheless important, changes in the relief were caused by underground mining of metal ores in the discussed area. Signs of small ancient wells and shallow open pits are typical for the following islands: Kea, Andros, Paros, Kythnos, Serifos, Sifnos, Milos, Kimolos, Lesbos, Samos and Thasos. Later, this exploitation also took place on Skyros, Skopelos, Andros, Syros, Naxos, Santorini, Tinos, Ikaria, Mykonos, Samothrace, Chios, Amorgos and Rhodes. Currently there is not a single ore mine functioning throughout the Aegean Islands. There are several quarries functioning in which mostly marble is extracted (on Thasos, Lesbos, Chios, Paros, Naxos and Tinos). The transformation of the relief is only progressing rapidly in relation to the openpit mining of rock materials of volcanic origin on Milos and Giali (Fig. 5). This is especially visible on the latter, where the large

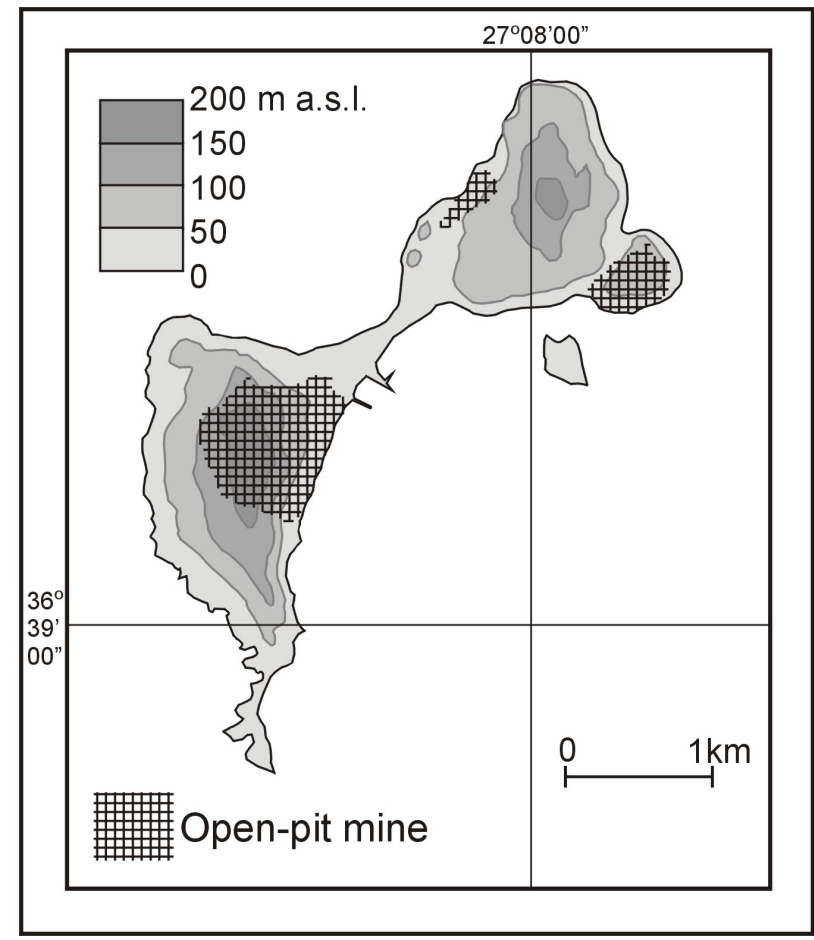

Figure 5. Transformations of the relief of the island of Giali related to the exploitation of perlite deposits.

mining area clearly contrasts with the small dimensions of the island.

The geomorphological consequences of the remaining forms of human activities on the Aegean Islands do not reach such significant levels as the elements mentioned above. Some of them are worth noting due to the fact that their history reaches back to ancient times. Among ancient forms, special attention should be paid to "depressions" of ancient theatres with a diameter of at least $50 \mathrm{~m}$, preserved up until today, for example on Thasos, Samothrace, Lesbos, Delos and Thira. On almost all of the islands, surfaces artificially levelled due to the construction 


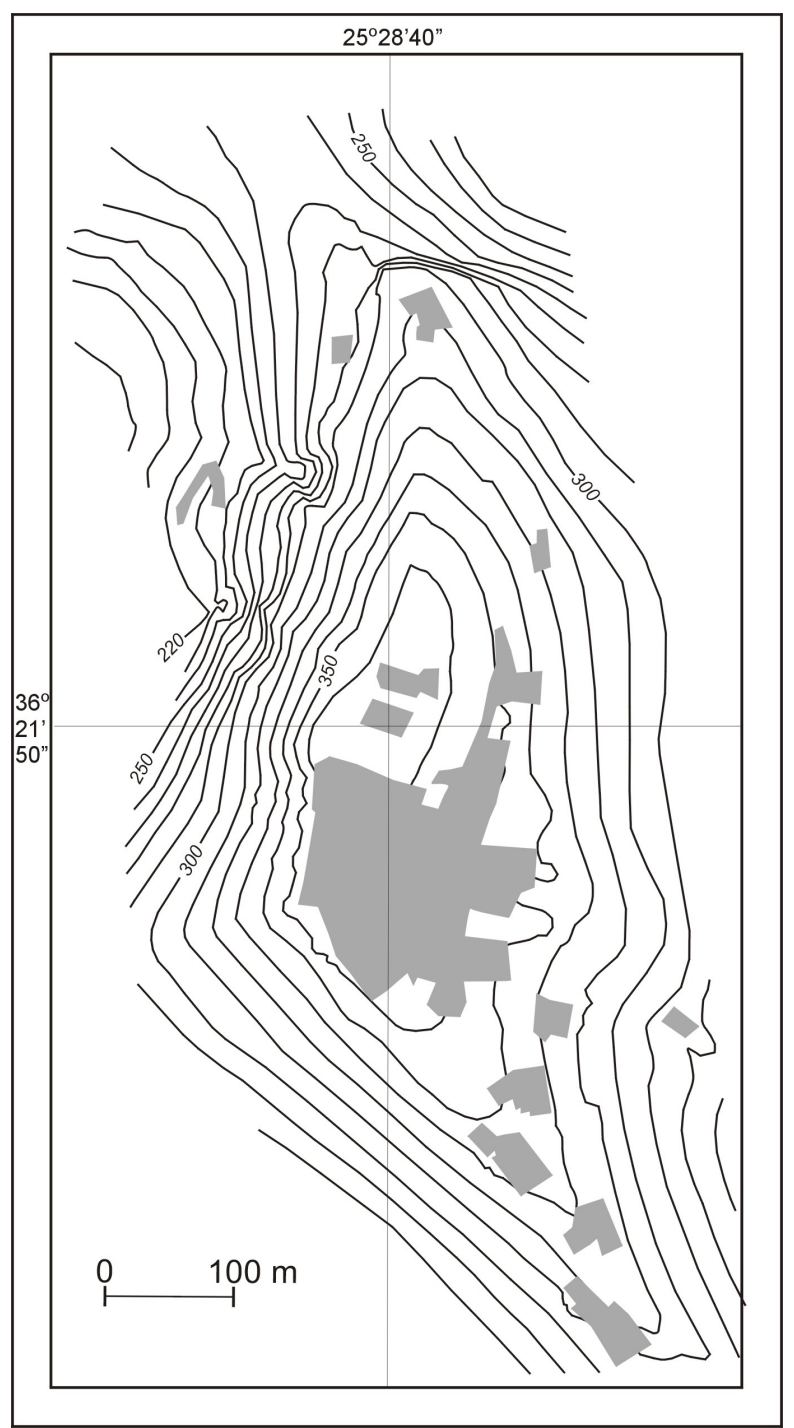

Figure 6. Defensive location of an ancient city of Thira on a partially artificially flattened hilltop. The sketch was based on the Topographic Map of Greece 1:50 000, Thira sheet.

of temples (Fig. 2G) and fortifications are also present - the majority of the defensive structures were located on transformed hilltops (Fig. 6).

The forms used to fulfil recreational needs are also relatively small. The largest of these include fragments of the ground levelled to build sports fields. Several areas of the Aegean beaches have also been partially transformed, but these forms should not be considered permanent, because they return to their natural state after most large storms.

\section{Human-induced geomorphological processes}

Contemporary relief evolution includes both natural changes and human-induced changes. Among the latter, signs of direct interference into the shape of particular landforms can be distinguished. However, the course of geomorphic processes has also been modified in an intentional or accidental manner as a result of different anthropogenic impacts (Goudie 2006). The Aegean Islands do not constitute an exception in this aspect.
Human impact in the region concerns mainly slope, fluvial and coastal processes.

The modification of the course of slope processes is mainly related to the transformations of natural vegetation and the change of the slope shape caused by the creation of agricultural terrace systems. The agricultural use of slopes without prior creation of terraces has been a rare phenomenon on the discussed islands and its spatial range has been extremely limited. The traditional form of land use on surfaces without terraces has involved pasturage, which has also taken place on abandoned agricultural terraces over the last few decades.

Generally, arable lands and permanent crops cover only 12 per cent of the surface area of the Aegean Islands; natural forests and quasi natural forests 7 per cent; depleted forests and shrubs approximately 6 per cent, while at least $1 / 5$ of the general surface area of the discussed islands is covered by pastures with more than a million sheep and goats, as well as nearly 30 thousand head of cattle (Statistical Yearbook of Greece 2008).

The course of the contemporary transformation of terraced slopes depends mainly on the lithological features of the ground and the current manner of land use. As can be concluded from the author's research (Tsermegas 2013), water erosion, which mostly involves cutting the walls separating different terrace levels, is visible within the abandoned fields. On those slopes where cultivation works are still conducted, all damage is quickly eliminated by farmers, while agrotechnical operations facilitate precipitation water infiltration into the soil profile, simultaneously limiting the effectiveness of surface runoff and erosion. Terraced slopes within volcanic tuffs (e.g. on Santorini), used as vineyards, where - due to economic reasons - the maintenance of strengthened terrace edges ceased, constitute an exception. On some of them erosion, starting several decades ago, has destroyed approximately 50 per cent of the terrace wall length $($ Fig. $2 \mathrm{H})$. It seems that the change in cultivation methods accelerates the destruction of the terraces to a greater extent than their complete abandonment. The significance of lithology is also manifested in the significant erosion resistance of the terraces built within carbonate surfaces. In the regions with resistant grounds, erosion processes are mostly only active during extreme precipitation events.

The rate of erosion on terraced slopes is highly influenced by how their profile has been changed in comparison to the natural state. The forms for which construction involved the presence of solid rock outcrops and those where terrace walls were constructed on outcrops are especially durable (Tsermegas et al. 2011).

The transformation of the relief of slopes on which abandoned agricultural terraces are located is highly dependent on whether uncontrolled grazing occurs within them. In the eastern part of the archipelago the relatively high precipitation promotes the restoration of vegetation which protects the surface from erosion. In the western and central part the climate is drier, so succession is much slower, and the abandoned terraces undergo faster degradation. From the author's research conducted on Ikaria and Santorini it can be concluded that the restored vegetation cover on the abandoned agricultural terraces constitutes perfect protection of the surface from water erosion. However, locally (e.g. in the places where fallen trees and previous terrace wall damage exist), rill erosion processes can develop (Tsermegas 2013). This confirms R. Lehmann's (1994) conclusions from studies conducted on the degradation of the abandoned fields on Naxos, that on surfaces covered by thick Mediterranean scrubs erosion is practically non-existent. However, if terrace walls are damaged, phrygana (especially common on the Cyclades) does not constitute efficient surface protection (Riedl 1994). 


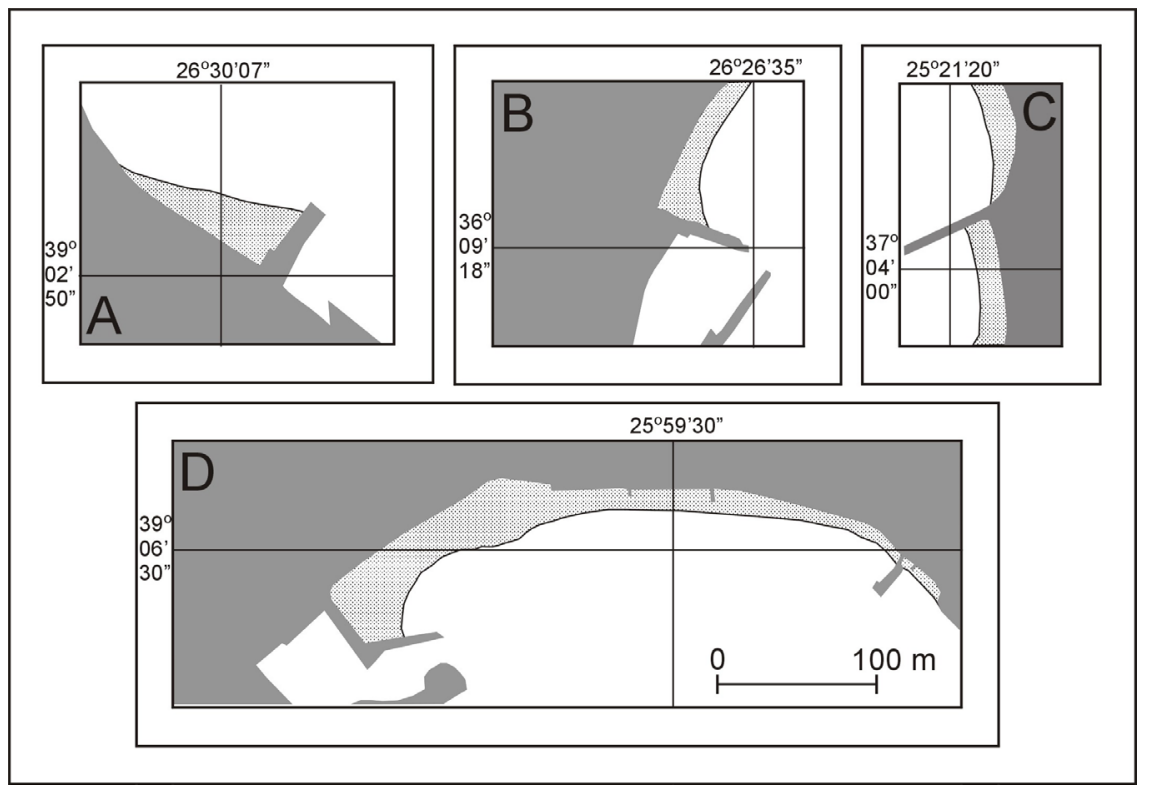

Figure 7. Examples of forced beach deposit accumulation (dotted areas) on Lesbos $(A, B, D)$ and Naxos (C)

Human activities on the Aegean Islands also have a local impact on the development of mass movements. This mostly concerns small rockfalls and landslides occurring as a consequence of the construction of roads (Tsagaratos, Koumantakis \& Rozos 2005), which are mainly activated in the winter period after heavy rains. Rockfalls occur mostly along road cuts, while landslides involve mainly road fill which is directly under the surface. More significant landslides, the activity of which may be partially connected to human activities, rarely occur on the Aegean Islands. The best known example is the landslide in the capital of Ikaria, which involved a significant part of the city, the movement of which was stopped as a result of supporting harbour construction (Rozos 1983).

The area of the Aegean Islands is divided by a dense network of river valleys. Their beds remain dry for most of the year. However, on all of these islands fluvial processes play an important role in relief transformation (Krzemień et al. 2012). The problem of how human activities are reflected in their course has interested geologists for a long time (Macklin \& Woodward 2009). It can be concluded from the author's observations that the greatest changes in the course of fluvial processes on the discussed islands correspond to a drastic decrease of discharge in summer (related to the damming of the channels and large water use for municipal and agricultural purposes; Tsermegas 2012b). Deforestation and agricultural use of the slopes (mainly grazing and the lack of maintenance of agricultural terraces) contribute to the increased material supply to the river channels. Additional routes of this supply include unsealed roads along slopes. Therefore, frequently during heavy rains, silting of river mouths occurs (Krzemień et al. 2012). On the other hand, extreme events, conditioned by the episodic occurrences of rainfall with an intensity exceeding $175 \mathrm{~mm}$ in 24 hours (Flokas \& Bloutsos 1980), make the most significant contribution to the transformation of riverbeds on the discussed area. The resulting flash floods wash away nearly all the consequence of channel processes caused by human activities.

The most important modification of the course of littoral processes on the discussed area results from the creation of barriers, which are perpendicular to the shoreline, and which stop sediment transported by longshore currents and favour erosion on the other side of the groyne (Fig. 7). The domination of high shores and a relatively small proportion of beaches results in the fact that this phenomenon is not common on the Aegean Islands, but it cannot be completely omitted.

\section{Conclusions}

From the quoted data it can be concluded that the largest (and oldest) changes in the relief caused directly by human activities on the Aegean Islands are related to the creation of road infrastructure and the construction of agricultural terraces. Currently, the construction of airports is turning out to be an important geomorphological factor, while in the past the construction of stone buildings was more significant. Particularly large anthropogenic landforms include artificial water reservoirs (created mainly during the last thirty years) and the landforms related to open-pit mining. In recent years significant changes in the relief have been caused by the construction of wind turbines, and this process will probably advance at an unprecedented rate in the near future.

Indirect human impact on the relief of the Aegean Islands, visible mostly through the modification of the course of morphogenetic processes, involves mainly slope, fluvial and coastal processes. Slope processes seem to be the most vulnerable. Extreme rainfall events effectively eliminate the morphological consequences of human impact on fluvial processes, while the permanent reflection of human impact in the course of coastal processes is limited to very short sections of the coast. 


\section{References}

Bakas, I \& Milios, L 2013, 'Municipal waste management in Greece', European Environment Agency, ETC/SCP, Copenhagen, pp. 1-15.

Betancourt, PP, Hope Simpson, R 1992, 'The agricultural system of Bronze Age Pseira', Cretan Studies, vol. 3, pp. 47-54.

Bintliff, JL 1977, 'Natural environment and human settlement in prehistoric Greece', Part I \& II, British Archaeological Reports, Supplementary Series, no 28, Oxford, B.A.R., pp. 1-734.

Broodbank, C 1999, 'Colonization and configuration in the insular Neolithic of the Aegean', in 'Neolithic society in Greece', ed. P Halstead, Sheffield Studies in Aegean Archaeology, vol. 2, pp. 15-41.

Brunet, M 1999, 'Le paysage agraire de Délos dans l'antiquité', Journal des savants 1999, no 1, pp. 1-50.

Flokas, AA \& Bloutsos, AA 1980, 'Computation of the maximum daily rainfall in Greece for various return periods' (in Greek), Proc. $2^{\text {nd }}$ Greek Seminar on Hydrology, pp. 185-196, Ministry of Coordination, Athens.

García-Ruiz, JM, Nadal-Romero, E, Lana-Renault, N, Beguería S 2013, 'Erosion in Mediterranean landscapes: Changes and future challenges', Geomorphology, vol. 198, pp. 20-36.

Geological Map of Greece 1:500 000, 1983, Institute of Geology and Mineral Exploration, Athens.

Giourga, C, Margaris, N \& Vokou, D. 1998, 'Effects of grazing pressure on succession process and productivity of old fields on Mediterranean island', Environmental Management, vol. 22, pp. 589-596. DOI: 10.1007/ s002679900130.

Goudie, AS 1993, 'Human influence in geomorphology', Geomorphology, vol. 7, pp. 37-59.

Goudie, A 2006, The Human Impact on the Natural Environment, 6 th ed. Blackwell, Oxford.

Grove, AT \& Rackham, O 2001, The Nature of Mediterranean Europe: An Ecological History, New Haven, Yale University Press.

Hooke, RL 2000, 'On the history of humans as geomorphic agents', Geology, vol. 28, no 9, pp. 843-846.

Kizos, Th \& Koulouri, M 2006, 'Agricultural landscape dynamics in the Mediterranean: Lesvos (Greece) case study using evidence from the last three centuries', Environmental Science and Policy, vol. 9, pp. 330-342.

Kizos, Th, Spilanis, I \& Koulouri, M 2007, 'The Aegean Islands: a Paradise lost? Tourism as a driver for changing landscapes, in Europe's living landscapes. Essays on exploring our identity in the countryside, eds. B Pedroli, A van Doorn, G de Blust, ML Paracchini, D Wascher, D \& F Bunce, Landscape Europe, KNNV, pp. 333-348.

Krzemień, K, Biejat, K, Dłużewski, M \& Tsermegas, I 2012 , 'Formy i procesy fluwialne w obszarze Morza Egejskiego na przykładzie Ikarii (Grecja)', Prace i Studia Geograficzne , vol. 49, pp. 119-136.

Laskaris, A, Sampson, A, Mavridis, F \& Liritzis, I 2011, 'Late Pleistocene/Early Holocene seafaring in the Aegean: new obsidian hydration dates with the SIMS-SS method', Journal of Archaeological Science, vol. 38, pp. 2475-2479.

Lehmann, R 1994, 'Landschaftsdegradierung, Bodenerosion und -Konservierung auf der Kykladeninsel Naxos, Griechenland', Physiogeographica, Basler Beitrage zur Physiogeographie, vol. 21, Basel.

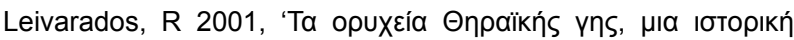

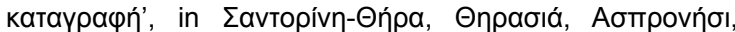
H paíoteıa, ed. IM Danezis.

Macklin, MG \& Woodward, JC 2009, 'River systems and environmental change', in The physical geography of the
Mediterranean, ed. JC Woodward, Oxford University Press Oxford, pp. 314-347.

Marsh, GP 1864 (ed. 2003), Man and nature, or, physical geography as modified by human action, Washington University of Washington Press, (reprint).

Michas, S, Economides, D \& Tsialas Th 2008, 'The role of dams in the water resources management of the Aegean Islands River Basin' (GR14) (in Greek), in 1st Pan-Hellenic Congress of Big Dams Records, 13-15.11.2008, Larissa, Technical Chamber of Greece.

Nir, D 1983, Man, a geomorphological agent, Keter Publ. House, Jerusalem

Papanastasis, VP 2007, 'Land abandonment and old field dynamics in Greece', in Old fields: dynamics and restoration of abandoned farmland, eds. VA Cramer \& RJ Hobbs, Society for Ecological Restoration International, Island Press, Washington, pp. 225-247.

Petmezas, S 2007, 'La "commune grecque": une tentative d'histoire des fictions historiographiques', in Bizantina et Moderna: Mélanges en l'honneur d'Héllène AntoniadisBibicou, eds. G Grivaud \& S Petmezas, Ekdoseis Alexandria, Athens, 207-232.

Podgórski, Z 2001, 'Antropogeniczne zmiany rzeźby terenu na obszarze Polski', Przegląd Geograficzny, vol. 73, no 1-2, pp. 37-55.

Riedl, H 1994, 'The human impact on soil erosion in Greece', Bulletin of the Geological Society of Greece, vol. 30, no 4, $7^{\text {th }}$ International Congress of the Geological Society of Greece, Thessaloniki, pp. 15-27.

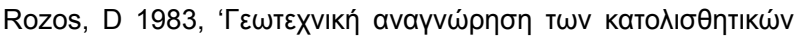

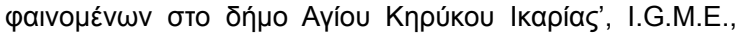
Athens.

Rozsa, P 2007, 'Attempts to qualitative and quantitative assessment of human impact on the landscape', Geografia Fisica e Dinamica Quaternaria, vol. 30, pp. 233-238.

Runnels, C 2014, 'Early Palaeolithic in the Greek Islands?', Journal of Mediterranean Archaeology, vol. 27, no 2, pp. 211-230.

Sampson, A 2010, Mesolithic Greece 9000-6500 BC: palaeoenvironment, palaeoeconomy, technology, Ekdoseis Ion, Athens.

Sampson, A, Kaczanowska, M, Kozłowski, JK, Athanassac, C, Bassiakos, Y, Liritzis, I, Laskaris, N \& Tsermegas, I 2012, 'Mesolithic occupations and environments on the island of Ikaria, Aegean, Greece', Folia Quaternaria, vol. 80, Kraków.

Statistical Yearbook of Greece 2008, National Statistical Service of Greece, Pireus.

Szabó, J 2006, 'Anthropogenic Geomorphology: Subject and System', in Anthropogenic Geomorphology: a guide to manmade landforms, eds. J Szabó, L Dávid \& D Lóczy, Springer, Debrecen, pp. 311.

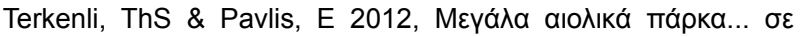

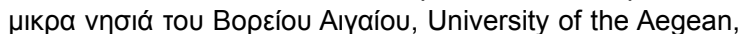
Department of Geography.

The dams of Greece, 2013, Greek Committee on Large Dams, Athens.

Tsagaratos, P, Koumantakis, J \& Rozos, D 2005, 'Landslide phenomena in granitic formations environments, geotechnical approach and classification, Eastern Aegean islands of Ikaria and Naxos, Greece', Geoline 2005, Lyon, 23-25 May, 2005, CD Rom.

Tsermegas, I 2012a, 'Rola człowieka we współczesnym modelowaniu rzeźby wyspy Ikarii (Grecja)', Prace Wydziału Nauk o Ziemi Uniwersytetu Śląskiego, no 77 („Antropopresja 
w wybranych strefach morfo klimatycznych - zapis zmian w rzeźbie i osadach"), Sosnowiec, pp. 402-409.

Tsermegas, I 2012b, 'Effects of human impact on the beds of minor watercourses of the Aegean Island of Icaria (Greece)', Quaestiones Geographicae, vol. 31(1), pp. 91-98. DOI 10.2478/v10117-012-0007-7.

Tsermegas, I 2013, Funkcjonowanie stoków starasowanych na Wyspach Egejskich, WGiSR UW, Warszawa.

Tsermegas I, Dłużewski M, Biejat K, Szynkiewicz A, 2011. Function of agricultural terraces in Mediterranean conditions - selected examples from the island of Ikaria (the Southern Sporades, Greece). Miscellanea Geographica 15, 65-78.

Whitelaw, TM 1994, 'An Ethnoarchaeological Study of Rural Landuse in North-West Keos: Insights and Implications for the Study of Past Aegean Landscapes', in Structures rurales et sociétés anciennes: Actes du Colloque de Corfou (14-1.05.1992), eds. PN Doukellis \& LG Mendoni, Annales Littéraires de l'Université de Besançon 508, Centre de recherches d'histoire ancienne 126. Paris, Belles Lettres, pp. $163-86$.
Wiener, MH 2013, 'Gaps, destructions, and migrations in the Early Bronze Age Aegean: causes and consequences', American Journal of Archaeology, vol. 117, pp. 581-592.

Yassoglou, N 2005, Soil Survey in Greece, in Soil Resources of Europe, $2^{\text {nd }}$ ed., in European Soil Bureau Research Report No.9, EUR 20559 EN, eds. RJA Jones, B Houskova, P Bullock \& L Montanarella, pp. 159-168.

YPEKA - Ministry of Environment, Energy and Climate Change, 2012, 'Catalogue of landfills' (in Greek) [http://www.ypeka. $\mathrm{gr} /$ LinkClick.aspx?fileticket=zj9Pd\%2bh03KQ\%3d\&tabid=4 38\&language $=\mathrm{el}-\mathrm{GR}]$ 